\title{
Outpatient Treatment for Humeral Fractures in Five Calves
}

\author{
Norio YAMAGISHI ${ }^{1) *}$, Bhuminand DEVKOTA ${ }^{1,2)}$ and Masahiro TAKAHASHI ${ }^{1,3)}$ \\ 1) Cooperative Department of Veterinary Medicine, Iwate University, Morioka, Iwate 020-8550, Japan \\ ${ }^{2)}$ Center for Biotechnology, Agriculture and Forestry University, Rampur, Chitwan, 44209, Nepal \\ ${ }^{3)}$ Department of Advanced Pathobiology, Graduate School of Life and Environmental Sciences, Osaka Prefecture University, Izumisano, \\ Osaka 598-8531, Japan
}

(Received 31 March 2014/Accepted 4 July 2014/Published online in J-STAGE 24 July 2014)

ABSTRACT. Humeral fractures were treated in 5 calves using unilateral external fixation with epoxy putty fixator (type I). The surgeries were performed under sedation and analgesia, and it involved application of ultrasound-guided brachial plexus block. The surgical procedures were completed in 60 to $90 \mathrm{~min}$, and each calf was returned to the farm on the same day. The fixation allowed each calf to remain with the dam and suckle without strict stall rest and was removed 11 to 62 days post-surgery. The clinical sign of diminished radial nerve function disappeared 40 days to 4 months post-surgery. These observations suggest that this repair technique represents a feasible outpatient treatment for humeral fractures in calves.

KEY WORDS: calf, epoxy putty fixator, humeral fracture, outpatient treatment, unilateral external fixation

doi: 10.1292/jvms.14-0170; J. Vet. Med. Sci. 76(11): 1519-1522, 2014

Humeral fractures occur infrequently in cattle accounting for less than $5 \%$ of all types of fracture and $18 \%$ of all longbone fractures $[3,8]$. These fractures are typically spiral or oblique through the diaphysis with different degrees of communication [12]. They may occur close to the radial nerve, which induces a considerable risk of permanent neurologic damage [3]. Several treatment options have been proposed for management of humeral fractures in cattle, including strict stall rest or internal fixation using plates and intramedullary pins $[3,8]$. Treatment methods depend on the size, age, temperament and economic value of the animals and past experience of the surgeons [3, 8]. In this report, we describe outpatient treatment for humeral fractures using external fixation $(\mathrm{EF})$ with the unilateral epoxy putty fixator (type I) in 5 calves. The surgery was performed under sedation and analgesia, and it involved application of ultrasound-guided brachial plexus block (uBPB).

One Holstein and 4 Japanese Black calves (2 to 106 days old and 38 to $83 \mathrm{~kg}$ ) were referred to the Veterinary Teaching Hospital of Iwate University to treatment suspected humeral fractures (Table 1). All calves had demonstrated non-weightbearing forelimb lameness for 2 to 7 days before arrival. Their clinical signs included the inability to fully extend the elbow and a dropped elbow posture, indicating diminished radial nerve function. Preoperative radiographs confirmed oblique midshaft (calves A, C, D and E) or comminuted supracondylar fractures (calf B) of the humerus (Fig. 1a).

Each calf was sedated by $0.1 \mathrm{mg} / \mathrm{kg}$ body weight (BW) of

*Correspondance to: Yamagishi, N., Cooperative Department of Veterinary Medicine, Iwate University, 3-18-8 Ueda, Morioka 020-8550, Japan. e-mail: yamagisi@iwate-u.ac.jp

(C2014 The Japanese Society of Veterinary Science

This is an open-access article distributed under the terms of the Creative Commons Attribution Non-Commercial No Derivatives (by-nc-nd) License $<$ http://creativecommons.org/licenses/by-nc-nd/3.0/>. xylazine (2\% Seractal; Bayer, Osaka, Japan) intravenously and administered $20 \mathrm{mg} / \mathrm{kg}$ BW of cefazolin (CefazolinChu; Fujita Pharmaceutical, Tokyo, Japan) and $1 \mathrm{mg} / \mathrm{kg}$ BW of flunixin meglumine (FORVET-50, Nagase Medicals, Itami, Japan) intravenously before surgery. The animals were positioned in lateral recumbency, and the affected limb was placed upward and prepared aseptically from the radius to the scapula. A $10-\mathrm{m} l$ lidocaine solution (2\% Xylocaine; AstraZeneca, Osaka, Japan) was administered to achieve analgesia by $\mathrm{uBPB}$ according to a method reported previously [5]. Additional intramuscular administration of xylazine $(0.05 \mathrm{mg} / \mathrm{kg} \mathrm{BW})$ was done to maintain the sedation at 50 to 60 min after the first xylazine administration.

Four calves (A to D) underwent fracture repair by open reduction. A curvilinear craniolateral incision starting from the point of the greater tubercle (calves A, C and D) or the distal diaphysis near the lateral condyle (calf B) of the humerus was extended distally to the lateral epicondyle or proximal radius, respectively, to provide access to the fracture site. The radial nerve was identified and reflected with the brachialis muscle as needed. Two calves underwent fracture repair by unilateral EF with percutaneous intramedullary pin placement through the greater tubercle (calf A) or the lateral and medial condyle of the humerus (calf $\mathrm{B}$ ). The remaining 2 calves ( $\mathrm{C}$ and $\mathrm{D})$ were treated by unilateral EF alone. Calf $\mathrm{E}$ underwent fracture repair by closed reduction and unilateral EF. The EF was structured by 3 to $53.2-$ or $4.0-\mathrm{mm}$ pins [Steimann intramedually pin (Part No. 10180 or Part No. 10532); IMEX Veterinary Inc., Longvew, TX, U.S.A.] or 2.4-mm pins (Kirschner wire; Mizuho Ikakogyo, Tokyo, Japan) using a Power Surgery Drill (Part No. 30010; IMEX Veterinary Inc.). Briefly, 1 or 2 pins were inserted percutaneously across the fracture plane to stabilize the fragments, and another 2 or 3 pins were percutaneously placed into both the proximal and distal fragments (Fig. 1b). The pins for EF were joined together with epoxy putty (Cemedine Epoxy 
Table 1. Clinical information of 5 calves with humeral fractures treated by external fixation

\begin{tabular}{|c|c|c|c|c|c|c|c|c|c|}
\hline $\begin{array}{l}\text { Calves } \\
\text { ID }\end{array}$ & Breed & Sex & $\begin{array}{c}\text { Age in } \\
\text { days (body } \\
\text { weight, } \mathrm{kg} \text { ) } \\
\text { on the treat- } \\
\text { ment day }\end{array}$ & $\begin{array}{l}\text { Duration of } \\
\text { the lameness } \\
\text { before the } \\
\text { treatment } \\
\text { day }\end{array}$ & Preoperative radiography & $\begin{array}{c}\text { Surgery } \\
\text { (reduction, } \\
\text { fixation) }\end{array}$ & $\begin{array}{l}\text { Duration } \\
\text { of surgery } \\
\text { (min) }\end{array}$ & $\begin{array}{l}\text { Post-surgical } \\
\text { pin removal } \\
\text { (days) }\end{array}$ & $\begin{array}{l}\text { Post-surgical } \\
\text { lameness } \\
\text { disappearance } \\
\text { (days) }\end{array}$ \\
\hline A & $\begin{array}{l}\text { Holstein } \\
\text { Friesian }\end{array}$ & Female & $106(83)$ & 3 & $\begin{array}{l}\text { Oblique midshaft fracture } \\
\text { of right humerus }\end{array}$ & Open, EF plus IP & 90 & 62 & 105 \\
\hline B & $\begin{array}{l}\text { Japanese } \\
\text { Black }\end{array}$ & Male & $16(45)$ & 7 & $\begin{array}{l}\text { Comminuted supracondy- } \\
\text { lar fracture of left humerus }\end{array}$ & Open, EF plus IP & 90 & 48 & 120 \\
\hline $\mathrm{C}$ & $\begin{array}{l}\text { Japanese } \\
\text { Black }\end{array}$ & Male & $7(41)$ & 7 & $\begin{array}{l}\text { Oblique midshaft fracture } \\
\text { of right humerus }\end{array}$ & Open, EF & 70 & 47 & 90 \\
\hline $\mathrm{D}$ & $\begin{array}{l}\text { Japanese } \\
\text { Shorthorn }\end{array}$ & Male & $8(45)$ & 5 & $\begin{array}{l}\text { Oblique midshaft fracture } \\
\text { of left humerus }\end{array}$ & Open, EF & 90 & 50 & 110 \\
\hline $\mathrm{E}$ & $\begin{array}{l}\text { Japanese } \\
\text { Black }\end{array}$ & Female & $2(38)$ & 2 & $\begin{array}{l}\text { Oblique midshaft fracture } \\
\text { of left humerus }\end{array}$ & Closed, EF & 60 & $11^{\mathrm{a})}$ & 40 \\
\hline
\end{tabular}

EF: external fixation, IP: intramedullary pin placement. a) The pins of EF were dropped out on day 11 of post-surgery due to biting by the dam.

Putty [for metal]; Cemedine, Tokyo, Japan) unilaterally at the extracorporeal position (Fig. 1c and 1d). Meanwhile, percutaneous intramedullary pin placement was performed in 2 calves (A and B) using two 2.4-mm Kirschner wires. The surgeries were completed in 60 to $90 \mathrm{~min}$ (Table 1).

Each calf was returned to the farm on the same day as surgery and administered the antibiotics for 4 to 6 days by the referring veterinarians. One calf (A) was confined individually to a small pen, and the remaining 4 (calves $\mathrm{B}$ to E) were reared in large pens together with their dams to allow for suckling. Follow-up information about postoperative conditions and outcomes was obtained from interviews with the owners or referring veterinarians, although 4 calves (A to D) were brought to the Veterinary Teaching Hospital for radiographic examination and removal of the EF under sedation with xylazine. The fixations in 3 calves (A, C and D) were removed 47 to 62 days post-surgery at the University Hospital (Fig. 1e and 1f). In calf B, the intramedullary pins were removed 2 weeks post-surgery by the referring veterinarian at the farm under sedation with xylazine, and the EF was removed 48 days post-surgery at the Veterinary Teaching Hospital under sedation with xylazine. In calf E, the EF dropped out 11 days post-surgery due to biting by the dam. The clinical sign of diminished radial nerve function disappeared within 40 days or within 3 to 4 months post-surgery (Table 1). Pin tract infection was identified by serous discharge from around the pin tracts at the time of EF removal in 2 calves (A and E), but it resolved on treating with initial systemic antibiotics and daily cleaning with sterile saline. All animals remained in good condition without apparent forelimb lameness for over 2 years, and all grew up normally and accomplished their productivity.

The treatment of humeral fractures in calves has been a challenge for the bovine orthopedic surgeons with little information available to guide the surgeons in choosing the most appropriate treatment plan [8]. In bovine medicine, strict stall rest is the most commonly chosen nonsurgical approach for management of humeral fractures, especially in young calves, because it is not associated with any costs or specific orthopedic skills $[3,8]$. Fractures amenable to this approach are those with minimal displacement or those in which the proximal fragment impacts the distal fragment providing some stability for healing [8]. Depending on the age and weight of the animals and the degree of fracture displacement, the animal should start to bear weight in 2 to 4 weeks with healing occurring in 2 to 3 months [8]. Pain associated with prolonged healing of an unstable fracture is undesirable. Carpal contracture in the injured limb, development of angular limb deformity and stretched flexor tendons in the opposite limb have been associated with prolonged convalescent periods [8,9]. Malunion with shortening of the limb and persistent lameness may also occur $[8,9,12]$. Instability and displacement without contact of the proximal and distal fragments decrease the chances of a favorable outcome without reduction and internal fixation [8,9]. At least in Japan, this conservative management is often unfavorable, since many farmers rear Japanese Black calves in pens together with their dams to allow for suckling, making it difficult to stabilize fractured limbs.

Internal fixation has been successful for the repair of bovine humeral fractures $[3,8]$. However, plate fixation is not an optimal technique performed frequently in clinical practice, because it requires expensive implants and equipments, surgical facilities, and specialized experience and anesthetic support for orthopaedic surgery [6]. Intramedually pin technique is another approach of internal fixation in repair of humeral fractures. An advantage of this technique over plating is that a surgical approach to the diaphysis of the humerus may be avoided in favor of a more limited surgical approach to the diaphysis for debridement and fracture reduction $[8,9,11,12]$. Intramedually pins are best suited to short oblique fractures or in combination with cerclage wires for long oblique fractures with minimal comminution [7], whereas this technique is not possible when there is extensive comminution [9].

In the present cases, the main request of the farmers was to repair the fractures by inexpensive surgical approach and to return the calves to the farms on the same day to rear together with their dams. Inhalation anesthetic equipments were not available in our hospital. Therefore, simple and 

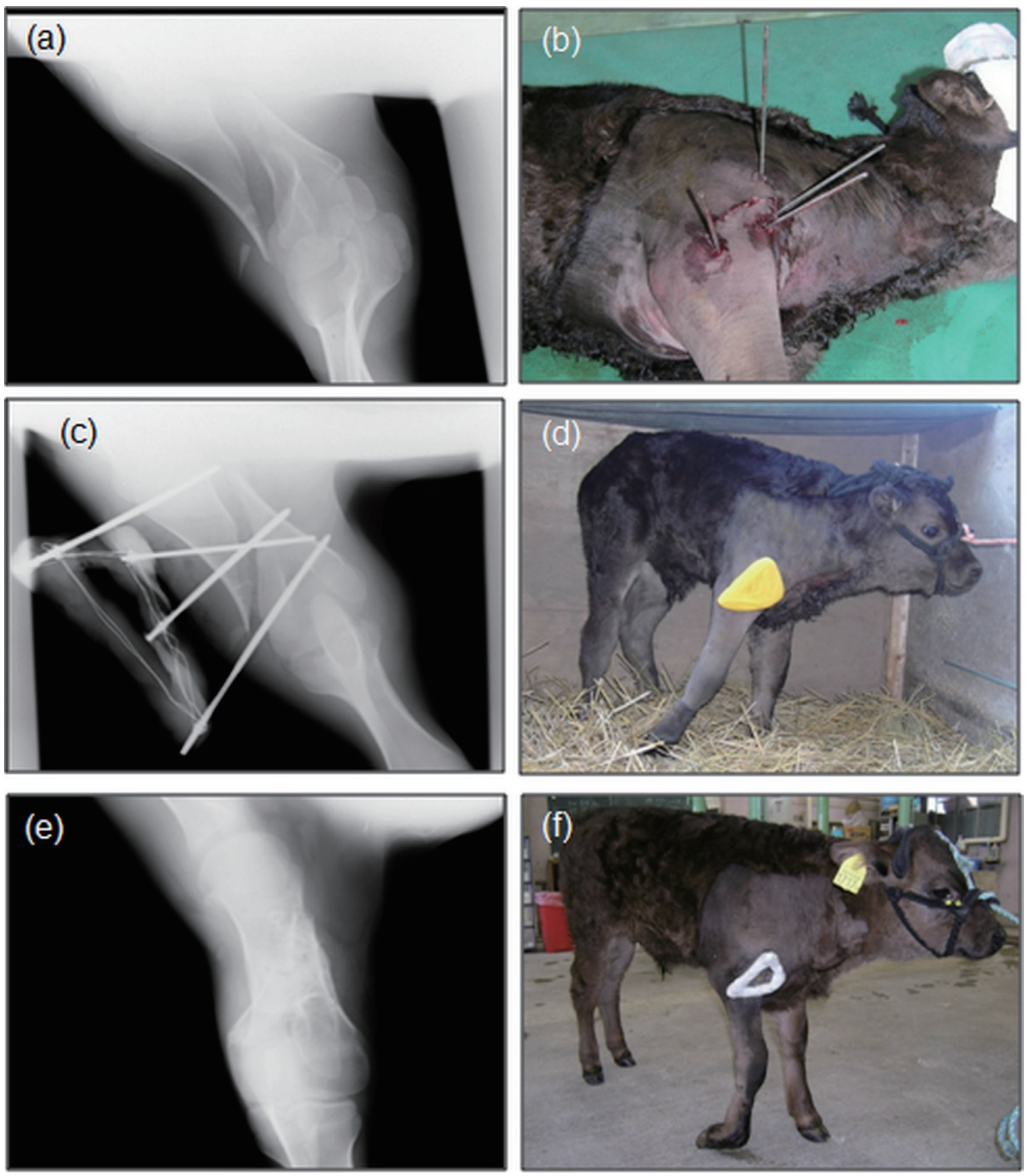

Fig. 1. Radiographs ( $a, c$ and e) and photographs ( $b, d$ and $\mathrm{f}$ ) of a Japanese Black calf (calf $\mathrm{C}$ ) with a right humeral fracture treated by external fixation (EF). (a) Caudocranial view of the humerus before surgery. (b) The surgical area after percutaneous pin placement for EF before joining 4 pins with epoxy resin. (c) Caudocranial view of the humerus after surgery. (d) Standing posture of the calf after surgery. (e) Caudocranial view of the humerus immediately after the removal of EF (47 days post-surgery). (f) Standing posture of the calf on the day of EF removal (47 days post-surgery). Even though clinical signs of diminished radial nerve function were still apparent, they disappeared by 90 days post-surgery.

feasible approach was required to effectively repair humeral fractures without special orthopedic instruments or rigorous effort to immobilize animals. In order to comply with those demands, we adopted EF as a treatment for the repair of humeral fractures. This EF was constructed by the pins inserted in the humerus and the unilateral splintage of epoxy putty (type I). This free-form external fixator has the advantage that pin direction and pin diameter are not influenced by direction of the connecting bar and size of the clamp, respectively [10]. Another advantage of using the epoxy putty 
is that it is inexpensive and readily available. The surgical procedure was not complicated compared to the plate fixation, even while applying open reduction (calves A to D) and percutaneous intramedullary pin placement (calves A and B) methods. The short surgical time was also considered to be an additional merit of the present approach for the repair of humeral fracture in calves.

In general, advantages of the EF for the treatment of limb fractures are early healing, preservation of local blood flow to the fracture site, preservation of bone stimulatory proteins that exude into the fracture site at the initial injury, diversity in design for comminuted fractures and ease of implant removal after clinical union of the fracture $[1,2,6]$. In the present cases, the period from surgery to the disappearance of diminished radial nerve function was shortest in the calf that underwent fracture repair by closed reduction (calf $\mathrm{E}$ ), suggesting that this approach may be more beneficial than open reduction method.

The most common clinical complications associated with $\mathrm{EF}$ are instability at the fracture site and pin tract infections $[1,2,4,6]$. In feline medicine, many patients with the femoral fractures treated with EF initially had a very slight serous discharge from around the pins; this was generally not a problem, and owners should be warned that it is likely to occur [6]. More substantial discharge is caused by loosening of the pin in the bone or continual damage to the soft tissue around the pin [6]. In the present cases, 1 or 2 pins of EF were inserted across the fracture plane to stabilize the fragments. This may be an effective approach to overcome the complication of instability at the fracture site associated with EF. The pin tract infection was observed in 2 cases (calves A and E), which was resolved by treating with systemic antibiotics and daily lavage. In the current study, intramedullary pin placement was performed only in 2 calves (A and $\mathrm{B})$; therefore further studies will be required to evaluate its effectiveness for stabilization of the fracture site in combination with the present approach of EF.

To the best of our knowledge, this is the first reported case series of outpatient treatment for humeral fractures in calves repaired by EF with the unilateral epoxy putty fixator under sedation and uBPB. The fixation allowed each calf to remain with the dam and sucklings without strict stall rest, suggesting that many owners are amenable to this treatment. We believe that this repair technique represents a feasible outpatient treatment for humeral fractures in calves and can be applied in the field of bovine practice.

ACKNOWLEDGMENT. We thank all staff members of the Veterinary Teaching Hospital of Iwate University for their support and the referring veterinarians for introducing the cases.

\section{REFERENCES}

1. Anderson, D. E. and St. Jean, G. 1996. External Skeletal fixation in ruminants. Vet. Clin. North Am. Food Anim. Pract. 12: 117-152. [Medline]

2. Anderson, D. E. and St. Jean, G. 2008. Management of fractures in field setting. Vet. Clin. North Am. Food Anim. Pract. 24: 567-582. [Medline] [CrossRef]

3. Ferguson, J. D. 1997. Surgical conditions of the proximal limb. pp. 262-276. In: Lamenesss in Cattle, 3rd ed. (Greenough, P. R. ed.), W. B. Saunders Company, Philadelphia.

4. Harari, J. 1992. Complications of external skeletal fixation. Vet. Clin. North Am. Small Anim. Pract. 22: 99-107. [Medline]

5. Iwamoto, J., Yamagishi, N., Sasaki, K., Kim, D., Devkota, B. and Furuhama, K. 2012. A novel technique of ultrasound-guided brachial plexus block in calves. Res. Vet. Sci. 93: 1467-1471. [Medline] [CrossRef]

6. Langley-Hobbs, S. J., Carmichael, S. and McCartney, W. 1996. Use of external skeletal fixators in the repair of femoral fractures in cats. J. Small Anim. Pract. 37: 95-101. [Medline] [CrossRef]

7. Markel, M. D., Nunamaker, D. M., Wheat, J. D. and Sams, A. E. 1988. In vitro comparison of three fixation methods for humeral fracture repair in adult horses. Am. J. Vet. Res. 49: 586-593. [Medline]

8. Rakestraw, P. C. 1996. Fractures of the humerus. Vet. Clin. North Am. Food Anim. Pract. 12: 153-168. [Medline]

9. Rakestraw, P. C., Nixon, A. J., Kaderly, R. E. and Ducharme, N. G. 1991. Cranial approach to the humerus for repair of fractures in horses and cattle. Vet. Surg. 20: 1-8. [Medline] [CrossRef]

10. Roe, S. C. and Keo, T. 1997. Epoxy putty for free-form external skeletal fixators. Vet. Surg. 26: 472-477. [Medline] [CrossRef]

11. Saint-Jean, G. and Hull, B. L. 1987. Conservative treatment of a humeral fracture in a heifer. Can. Vet. J. 28: 704-706. [Medline]

12. Tulleners, E. P. 1986. Management of bovine orthopedic problems. Part 1. Fractures. Compend. Contin. Educ. Pract. Vet. 8: S69-S80. 